\section{An Analysis from the English School Perspective on conflict issues in the Arctic Region of the Russian Federation and the United States}

Rusya Federasyonu ve Amerika Birleşik Devletleri'nin Arktik Bölgesi'ndeki uyuşmazlik konularına yönelik İngiliz Okulu Perspektifi'nden bir analiz

\author{
Ebru Caymaz ${ }^{1}$ \\ Y. Barbaros Büyüksağnak ${ }^{2}$
}

\begin{abstract}
When the current literature on RF and the USA's Arctic doctrines, strategies and disputes are examined, it is seen that there are two basic approaches that provide analyzes from realist and liberal perspectives. A large body of these analyzes focus on singular and linear dimensions, primarily on energy security and military issues. The number of studies which examine the dimensions of the conflict from a realistic perspective and synthesize with the cooperation and governance offered by the liberal perspective is relatively low. There is a need for a more in-depth understanding of the region, so extensive studies involving multidisciplinary dimensions that can promote collaboration and expertise sharing as well as resolution of disputes among security actors. In this study, the subject dispute matters were examined from the perspective of English School, which can present a unique framework by synthesizing the traditions of realism, rationalism and revolutionism. In conclusion
\end{abstract}

Özet

RF ve ABD'nin Arktik politika, doktrin, strateji ve uyuşmazlık konularını ele alan güncel literatür incelendiğinde realist ve liberal bakış açılarından analizler sunan iki temel yaklaşımın olduğu görülmektedir. Söz konusu analizlerin büyük bir kısmı başta enerji güvenliği ve askeri konular olmak üzere, tekil ve doğrusal boyutlar üzerine odaklanmaktadır. Uyuşmazlık boyutlarını realist bir bakış açısıyla irdeleyerek, liberal perspektifin sunduğu iş birliği ve yönetişimle sentezleyebilen çalışma sayısı ise oldukça azdır. Bölgeye yönelik daha derinlikli bir anlayışı, dolayısıyla, güvenlik aktörleri arasında uyuşmazlıkların çözümünün yanı sıra iş birliği ve uzmanlık paylaşımını teşvik edebilecek çok disiplinli boyutların analize dâhil edildiği kapsamlı çalışmalara ihtiyaç bulunmaktadır. $\mathrm{Bu}$ çalışmada bahsi geçen uyuşmazlık konuları, gerçekçilik (realism), akılcilik (rationalism) ve devrimcilik (revolutionism) geleneklerini sentezleyerek özgün bir çerçeve sunabilen İngiliz Okulu perspektifinden irdelenmiştir. Sonuç

${ }^{1}$ Dr. Öğr. Üyesi, Çanakkale Onsekiz Mart Üniversitesi, (DD Orcid ID: 0000-0002-9119-7659 ebru.caymaz@comu.edu.tr 2 Ö̆gretim Görevlisi, Pîrî Reis Üniversitesi, (D) Orcid ID: 0000-0003-1951-2121 ybbuyuksagnak@pirireis.edu.tr. 
Caymaz, E., \& Büyüksağnak, Y. B. (2021). Rusya Federasyonu ve Amerika Birleșik Devletleri'nin Arktik Bölgesi'ndeki uyuşmazlık konularına yönelik İngiliz Okulu Perspektifi'nden bir analiz. Journal of Human Sciences, 18(1), 76-93. doi:10.14687/jhs.v18i1.6094

part, possible solution suggestions in accordance with the international law for the resolution of disputes are discussed within a broader framework offered by the English School perspective. In addition, the role and functions of the People's Republic of China (PRC) in the struggle for dominance of the region as the third actor, which led to various discussions with large-scale investments and cooperation agreements across the region, were also included. In today's world where powerbased approaches are replaced by binding international rules, it is concluded that in order to develop the cooperation in the Arctic Region, the international community, especially in terms of the the littoral states; developing policies that support joint scientific studies and prioritize measures to increase the socio-economic conditions and human development levels of indigenous peoples and communities living in the region are more significant than being a commercial and economic gain center provided by the rich energy resources and new maritime trade routes which emerged due to global warming.

Keywords: Arctic, US Arctic Doctrine, English School, RF Arctic Doctrine, Dispute Analysis. bölümünde anlaşmazlıkların çözümü için uluslararası hukuka uygun olası çözüm önerileri İngiliz Okulu yaklaşımının sunduğu daha geniş kapsamlı bir çerçevede tartışılmıştır. Ayrıca bölgeye yönelik büyük çaplı yatırımları ve iş birliği anlaşmaları ile çeşitli tartışmalara yol açan Çin Halk Cumhuriyeti'nin (ÇHC) üçüncü aktör olarak bölge hâkimiyet mücadelesindeki rolü ve işlevi de incelemeye dâhil edilmiştir. Güç temelli yaklaşımların yerini, bağlayıcılığ1 bulunan uluslararası kuralların aldığ1 günümüzde Arktik Bölgesi'ndeki iş birliği potansiyelinin geliştirilebilmesi için başta kıyıdaş devletler olmak üzere uluslararası toplumun; küresel 1sınma nedeniyle ortaya ç1kan zengin enerji kaynaklarının ve yeni deniz ulaşım / ticaret yollarının sunduğu ticari ve ekonomik bir kazanç merkezi olmaktan ziyade ortak bilimsel çalışmaları destekleyen ve bölgede yaşayan yerli halkların ve toplulukların sosyoekonomik koşullarını ve insani gelişim düzeylerini artıracak önlemleri önceleyen politikalar geliştirmelerinin daha önemli olduğu sonucuna ulaşılmıştır.

Anahtar Kelimeler: Arktik, ABD Arktik Doktrini, Ingiliz Okulu, RF Arktik Doktrini, Uyuşmazlık Analizi.

\section{(Extended English summary is at the end of} this document)

\section{Giriş}

Literatürde Rusya Federasyonu'nun (RF) Arktik politikalarına ilişkin oldukça farklı görüşler bulunmaktadır. RF'nin Arktik Bölgesi'ndeki stratejik bombardıman devriye uçuşlarına devam etme kararı, 2007 yllının Ağustos ayında Kuzey Kutup noktasında okyanusun zeminine titanyumdan yapılmış Rus bayrağını yerleştirmesi ve 2008 yllında yayımladığı Arktik Stratejisi’nin kapsamı, Arktik politikalarının saldırgan, yayılmacı ve 'güç diplomasisi'ne dayalı olduğuna dair ciddi eleştirilere yol açmıstır (Kraska, 2009; Schepp ve Traufetter, 2009; Willet, 2009).

Diğer yandan, ideolojik veya jeopolitik faktörlerin yön verdiği Soğuk Savaş döneminin aksine RF'nin mevcut Arktik doktrini, Moskova'nın doğal kaynaklar için rekabet ve / veya Kuzey Deniz Yolu'nun kontrolü gibi pragmatik çıkarları ile açıklayan görüşler de bulunmaktadır. Bu nedenle RF'nin Arktik Bölgesi’ne yönelik niyetlerini esas itibarıyla meşru çıkarlarının korunmasına yönelik savunmacı olarak kabul eden (Alexandrov, 2009; Belov, 2012; Oreshenkov, 2009), ya da en azından uluslararas1 Arktik iş birliği bağlamında diğer Arktik devletlerinin talepleri kadar kabul edilebilir bulan (Heininen, 2011) çalışmalar mevcuttur. Söz konusu çalışmalarda, Moskova'nın birincil ilgisinin doğal kaynaklar açısından zengin ve yerel ekonomi, altyapı, iletişim sistemleri, sosyal kurumlar ve kültür açısından az gelişmiş RF Arktik Bölgesi'nin gelişimi olduğu vurgulanmaktadır. Bu görüşe göre, Moskova 
Caymaz, E., \& Büyüksağnak, Y. B. (2021). Rusya Federasyonu ve Amerika Birleșik Devletleri'nin Arktik Bölgesi'ndeki uyuşmazlık konularına yönelik İngiliz Okulu Perspektifi'nden bir analiz. Journal of Human Sciences, 18(1), 76-93. doi:10.14687/ihs.v18i1.6094

revizyonist bir Arktik politikası izlemediği gibi bilakis bölgede karşılaştı̆̆ tüm uyuşmazlık hususlarını uluslararası örgütlere taşıyarak, uluslararası hukukun sunduğu barışçıl yollarla çözme gayretindedir.

Amerika Birleşik Devletleri’nin (ABD) güncel Arktik doktrini ise birçok alt başlık içermektedir. ABD için Arktik Bölgesi öncelikle stratejik noktalarda ikmal kabiliyeti sağlayan deniz ve hava sistemlerinin konuşlandırıldığı, Arktik Okyanusu'nda varlığını gösterme ve deniz güvenliği operasyonları ile seyir ve üst geçiş uçuş serbestliğinin ve stratejik caydırıcılığın sağlandığı füze savunma ve erken uyarı sistemleri dâhil askeri ve stratejik çıkarlarının bulunduğu önemli bir bölgedir. Buna ek olarak, ABD'nin Arktik Bölgesi'ni saldırıya açık hale getirebilecek her türlü terörist veya diğer suç eylemlerini önlemeye yönelik ulusal çıkarları bulunmaktadır. Son olarak, ABD'nin bölgeye yönelik ekonomik ve siyasi çıkarları nedeniyle bölgedeki varlığını ve faaliyetlerini genişletmek, deniz gücünü artırmak açısından da büyük öneme sahiptir (DOD, 2013).

Yukarıda yer verilen bilgilerden hareketle güçlü devletlerin yer aldığ1 Arktik Bölgesi’nde gündeme gelen kıta sahanlığına ilişkin uyuşmazlıklar anlaşılabilir bir olgudur. Türkçe literatürde RF ve ABD'nin Arktik Bölgesi'nde yaşadıkları uyuşmazlıkları inceleyen pek çok çalışma bulunmakla birlikte mevcut çalışmalar genellikle realist teori çerçevesinde analizler sunmaktadır. Küreselleşmeyle birlikte aktörlerin çeşitlendiği günümüz dünyasında hem doğal kaynaklar hem de deniz ticaret yolları açısından büyük potansiyel barındıran ve geçmişte de birçok uyuşmazlı̆ga konu olan Arktik Bölgesi gibi çok uluslu bir bölgede ABD ve RF gibi güçlü aktörler arasında meydana gelen ve birçok farklı değişken içeren uyuşmazlık konularını salt realizm bağlamında analiz etmek, mevcut analizlerin kapsam bakımından sınırlı kalmasına neden olmuştur. Bu çalışmada söz konusu uyuşmazlık konuları, gerçekçilik (realism), akılcılık (rationalism) ve devrimcilik (revolutionism) ${ }^{3}$ geleneklerini sentezleyerek özgün bir çerçeve sunabilen İngiliz Okulu perspektifinden (Devlen ve Özdamar, 2010) irdelenecek ve anlaşmazlıkların çözümü için uluslararası hukuka uygun olası çözüm önerileri İngiliz Okulu yaklaşımının sunduğu daha geniş kapsamlı bir çerçevede tartşılacaktır. Ayrıca bölgeye yönelik yatırımları ve iş birliği anlaşmaları ile çeşitli tartışmalara yol açan Çin Halk Cumhuriyeti'nin (ÇHC) üçüncü aktör olarak bölge hâkimiyet mücadelesindeki rolü ve işlevi de incelemeye dâhil edilecektir.

\section{1. İngiliz Okulu: Kökeni, Temel Varsayımları ve Yöntemi}

İngiliz Okulu, 2. Dünya Savaşı sonrasında Herbert Butterfield, Martin Wight, Adam Watson ve Hedley Bull öncülüğ̈ünde İngiltere'de ortaya çıkan bir uluslararası ilişkiler (Ui) kuramıdır. Özellikle Wight'in Londra İktisat Okulu'nda verdiği dersler, hem İngiltere'de hem de ülke dişında birçok uluslararası ilişkiler öğrencisini etkilemiş, ismi verilen akademisyenlere ait çalışmaların Bull tarafindan toparlanmasıyla birlikte İngiliz Okulu'nun kurumsallaşma süreci başlamıştır. Öte yandan kuram, her ne kadar İngiliz Okulu olarak adlandırılsa da, örneğin E. H. Carr, A.W. Manning gibi İngiltere'de çalışan tüm Uİ kuramcılarını kapsamamaktadır (Brown, 1997).

Diğer Uİ kuramları ile kıyaslandığında İngiliz Okulu’nun öne çıkan en önemli özelliği eklektik bir yapıya sahip olmasıdır. Bir diğer ifade ile birden fazla dünya görüşünü birleştirerek kullanma imkânı sunmasıdır. İngiliz Okulu'nun kurucusu kabul edilen Martin Wight, tarihsel süreçte uluslararası ilişkiler davranışını betimleyen üç geleneksel okulun kendi siyasal düşüncesine katkısını açıklamıştır. Wight tarafindan daha en başta önemi vurgulanan üç geleneksel okul; Grotiuscu akılcılık, Makyavelci (ya da Hobbescu) gerçekçilik ve Kantçı devrimciliktir (Wight, 1991). Uluslararası ilişkiler, Makyavelciler tarafindan çatışma bağlamında incelenmektedir. Kantçı devrimciler ise farklı devletlerde yaşayan insan topluluklarının veya toplum sınıflarının, ortak çıkar, fikir ve ideolojiler çerçevesinde birlikte hareket edebileceklerini ileri sürmektedir (Dunne, 1998; Devlen vd., 2005).

\footnotetext{
${ }^{3}$ Burada akılcılık olarak yer verilen "rationalism"den kasıt, İngiliz Okulu literatüründe yer alan "Grotian realism”dir. Diğer yandan "devrimcilik"ten kasıt, Kantçı devrimciliktir. Nuri Yurdusev akılcılık için "makuliyetçilik", devrimcilik için "radikalizm” terimlerini kullanmıştır. Daha fazla bilgi için bkz. Nuri Yurdusev, "Uluslararası İlişkiler Öncesi”, Devlet Sistem ve Kimlik: Uluslararası İlişkilerde Temel Yaklaşımlar, Atila Eralp (der.), İstanbul, İletişim Yayınları, 1996, s. 47-51.
} 
Caymaz, E., \& Büyüksağnak, Y. B. (2021). Rusya Federasyonu ve Amerika Birleșik Devletleri'nin Arktik Bölgesi'ndeki uyuşmazlık konularına yönelik İngiliz Okulu Perspektifi'nden bir analiz. Journal of Human Sciences, 18(1), 76-93. doi:10.14687/jhs.v18i1.6094

17. yüzyıl hukuk felsefecisi Hugo Grotius'tan esinlenerek ortaya çıkan Grotiuscu akılc1lığa göre akıl, bilginin tek kaynağı değildir; hukukun kaynağı ise sosyal olayların ve ilişkilerin gözlemlenmesinin yanı sıra bunların çıkarımlar yoluyla çözümlenmesidir. Grotiuscu akılcılık, hukuk literatüründe yer alan "ilahi hukuk", "pozitif hukuk" ve "pozitif tabii hukuk" ayrımında pozitif tabii hukuka daha yakındır. Bu haliyle diğer iki çerçevenin arasında konumlanan Grotiuscu akılcilı̆̆a göre UI'de devletlerin yarattığ bir toplum vardır ve temel varsayım devletlerin esas itibarıyla "dayanışmacı" (solidarist) oldukları ve bu durumun da hukuk kurallarına riayet eden bir uluslararası toplumun oluşumuna katkı sağladığıdır (Bull, 1966).

Grotiuscu yaklaşımın Makyavelci ve Kantçı yaklaşımlar arasında konumlandığını öne süren Bull ve Wight, İngiliz Okulu'nu da bu çerçeveye oturtmuştur (Wight, 1966). Bu noktada bilhassa belirtilmesi gereken, bu çalışmanın temel varsayımları arasında yer alan görüşe paralel olarak, Grotiuscular hem realistlerin ileri sürdüğ̈ dünya siyasetini devletler arası çatışmaların belirlediği düşüncesine katılmaz, hem de devrimcilerin ütopik yaklaşımlarını eleştirirler. Grotiuscu bakış açısına göre politika, "devletler toplumu" veya "uluslararası toplum" çerçevesinde tanımlanır. Bu açıdan bakıldığında İngiliz Okulu, devletleri uluslararası sistemin temel aktörleri olarak kabul ettiği için realistlere, devrimlerin dünya siyaseti üzerindeki etkilerini kabul ettikleri için de Kantçı devrimcilere daha yakındır. İngiliz Okulu'nun söz konusu görüşlerden farklılaştı̆̆ı nokta ise Makyavelciler gibi devletler arası çatışma hali ile Kantçılar gibi devletler arası çıkarların birebir uyuşabileceğine yönelik görüşleri kabul etmemesidir. Bu bilgilerden hareketle İngiliz Okulu, uluslararası toplumun, çatışma ve iş birliğinin bir arada gözlemlenebileceği sosyal ve ekonomik ilişkiler bütünü olduğunu savunur. Uİ kuramcılarının da incelemesi gereken bu ilişkiler bütünüdür (Bull, 1977).

Devlet - merkezci bir analiz çerçevesi kullanan İngiliz Okulu'na göre uluslararası siyaset, devletlerin stratejik etkileşimlerinin bir sonucu iken, uluslararası toplumun önemi kabul edilse de analizlerin temelinde devlet yer alır (Little, 1998). Wight'a (1977) göre devletler-sistemi açık ve sınırları belirsiz bir sistemdir; genişleyip daralabilir. Sovyet Sosyalist Cumhuriyetler Birliği (SSCB) bu konuya örnek olarak verilebilir. 2. Dünya Savaşı'nın ardından oluşan sistem, SSCB'nin aniden çökmesiyle sonlanmıştır. Bu bilgilere ek olarak, İngiliz Okulu kuramciları literatüre "uluslararası emperyal sistemler" kavramını da kazandırmışlardır. Okulun kurucuları, politik bir örgütlenme biçimi olarak emperyal sistemleri incelemiş ve bahsi geçen sistemlerin devletler-sistemleriyle paralel olarak varlıklarını devam ettirebileceklerini öne sürmüşlerdir (Watson, 1987). Ayrıca uluslararası sistemlerin uluslararası toplumlara nasıl dönüştüğü sorusu cevaplanmaya çalışılmış; ortak amaç, çıkar ve kuralların bir toplum yaratmaya yetip yetmeyeceği tartısılmıştır (Wight, 1953).

Yukarıda yer verilen bilgilerden hareketle İngiliz Okulu'nun temelini oluşturan argümanlara aşağıda yer verilmiştir:

- Egemen devletler (şehir devleti veya ulus-devlet), uluslararası ilişkilerin temel oyuncularıdır.

- İki veya daha fazla devletin aralarında ilisski olması ve birbirlerinin kararlarına etki edebilmeleri devletler-sisteminin varlığını gösterir.

- Uluslararası sistemin anarşik olması, ortak hükümet olmaması demektir.

- Devletler, uluslararası sistemde "uluslararası toplum" içinde var olurlar. Söz konusu uluslararası toplum, ortak çıkarlar ve değerler bağlamında devletleri sınırlayan ilişkileri düzenleyen ortak kurallar ve birlikte yürütülen kurumlardan oluşur (Bull, 1986; Devlen ve Özdamar, 2010).

İngiliz Okulu yöntembilimsel açıdan incelendiğinde ise kuramcıların çalışmalarında bu konunun nispeten eksik kaldığ1 söylenebilir. Bununla birlikte neredeyse bütün İngiliz Okulu kuramcıları analizlerinde klasik, tarihsel yöntemi kullanmışlardır. Bu nedenle UI literatüründe klasik tarafta kabul edilseler de Little (1995) bu sınıflandırmanın yanlış olduğunu ifade eder. Ancak dört kurucunun eserleri daha yakından incelendiğinde Watson ve Butterfield'ın tarihsel, Wight ve Bull'un ise tarihsel ve felsefi çözümlemeleri tercih ettikleri görülmektedir. Wight'nn üç geleneğinden de 
Caymaz, E., \& Büyüksağnak, Y. B. (2021). Rusya Federasyonu ve Amerika Birleșik Devletleri'nin Arktik Bölgesi'ndeki uyuşmazlık konularına yönelik İngiliz Okulu Perspektifi'nden bir analiz. Journal of Human Sciences, 18(1), 76-93. doi:10.14687/ihs.v18i1.6094

yararlanılması eklektif bir çerçeve sunarak; sistemik, toplumsal ve dünya toplumu düzeylerinin hepsinin analiz düzeyi olarak kullanılabilmesine olanak tanımıştır.

Bu bilgiler minvalinde bu çalısma kapsamında öncelikle RF ve ABD’ye ait Arktik doktrinlerin tarihsel süreçteki değişimlerine yer verilerek, daha sonra söz konusu bölgedeki RF - ABD uyuşmazlıkları tarihsel bir yaklaşımla irdelenmiştir.

\section{Rusya Federasyonu'nun Arktik Doktrini}

RF, 1997 yllında Birleşmiş Milletler Deniz Hukuku Sözleşmesi'ni (BMDHS) imzaladıktan sonra 2001 yılında BM'ye başvurarak Arktik Bölgesi'ndeki kıta sahanlığını genişletme hakkını arayan ilk devlettir. Ayrıca Arktik devletleri arasında resmi Arktik stratejisini geliştirerek, Arktik doktrinini şekillendiren ilk devletlerden biridir. RF'nin Arktik Bölgesi'ne yönelik ilgisi, Sovyetler Birliği donanmasının 1910-1915 yılları arasında ticari amaçlar için Kuzey Deniz Yolu'nu (NSR) keşfetmeye yönelik seferleriyle başlamış ve ilk başarılı seyir yine bu tarihlerde gerçekleşmiştir (The Stimson Center, 2013). 1926 yılına gelindiğinde ise Sovyetler Birliği kuzeydeki sınırlarını belirleyerek, Kola Yarımadası, Kuzey Kutup Noktası ve Bering Boğazı arasında kalan bölge üzerinde hak talebinde bulunmuş; söz konusu hak taleplerini 1928 ve 1950 yıllarında yinelemiştir (Astrasheuskaya ve Foy, 2019). 1930'lu y1llarda askeri açıdan bölgeye ilgi göstermeye başlayan Sovyetler Birliği, bunun yanında hızlı bir sanayileşme politikasını da uygulamaya koymuştur (The Stimson Center, 2013). Soğuk Savaş döneminde SSCB ve ABD arasında jeopolitik ve jeostratejik bir rekabet sahasına dönüşen Arktik Bölgesi'nde birçok askeri üs kurularak hızla silahlandırılmıştır (Huebert, 2019).

1980'li yıllarda SSCB'nin karșı karşıya kaldığı sosyo-ekonomik krizler, dönemin lideri Mihail Gorbaçov'un daha uzlaşmacı bir dış politika izlemesini teşvik etmiştir. (Atland, 2008) Bu noktada Gorbaçov'un 1 Ekim 1987 tarihinde Murmansk'ta yaptığı dikkat çeken konuşmasında Arktik Bölgesi için kullandığı "barış bölgesi" söylemi oldukça dikkat çekicidir. Coğrafi açıdan Arktik Bölgesi’nin Asya, Avrupa ve Amerika kıtalarını buluşturduğuna vurgu yaparak bölgedeki sorunların, ikili ve çok taraflı işbirlikleriyle çözülmesi çağrısında bulunmuştur. Gorbaçov’un söz konusu 1lımlı yaklaşımının ardından bölgedeki askeri unsurların önemli ölçüde azaltıldığı; başarılı bir çevre yönetimi ve kaynakların sürdürülebilirliğini sağlamak amacıyla bölge devletleri arasında ikili ve çok taraflı diyalogların başlatıldığı görülmektedir (Heininen, 2014).

2001 yılında BM'ye yapılan başvuruyla birlikte kıta sahanlığını 200 deniz milinin ötesine genişletmeyi amaçlayan RF, uluslararası hukuk kurallarına dayandırmaya çalıştığı hak talebi ile Arktik Okyanusu sularının altında zengin hidrokarbon enerji kaynaklarını barındıran $1.200 .000 \mathrm{~km}^{2}$ lik Lomonosov Sırtı ve Alpha-Mendelev sıradağları üzerinde egemenlik iddiasında bulunmuştur (Osterud ve Honneland, 2014). Aynı yıl 14 Haziran'da Rusya Hükümeti, RF'nin Arktik Bölgesi'ndeki ulusal çıkarları ve temel stratejilerinin ana hatlarının yer aldığ1 "Foundations of the State Policy of the Russian Federation in the Arctic" (RF'nin Arktik Bölgesi Devlet Politikasının Temelleri) başliklı taslak dokümanı onaylamış; söz konusu dokümana 2008 yılında nihaî hali verilmiştir. "State Policy of the Russian Federation in the Arctic to 2020 and Beyond' (Rusya Federasyonu'nun 2020 Y1lı ve Ötesine Yönelik Arktik Devlet Politikası) ismiyle onaylanan bu 6 sayfalık dokümanda RF’nin Arktik Bölgesi’ndeki ulusal çıkarları şu şekilde sıralanmıştr:

- Arktik Bölgesi'nde yer alan kaynakların geliştirilmesi,

- Kuzey Deniz Yolu'nun ulusal bir ulaşım koridoru ve iletişim hattına dönüştürülmesi,

- Bölgenin uluslararası bir iş birliği bölgesi olarak korunması.

\footnotetext{
${ }^{4}$ Bknz. Mikhail Gorbachev's Speech in Murmansk at the Ceremonial Meeting On the Occasion of the Presentation Of the Order of Lenin and the Gold Star to the City of Murmansk, 1 Ekim 1987, https://www.barentsinfo.fi/docs/Gorbachev speech.pdf (Erişim Tarihi 1 Eylül 2020).
} 
Caymaz, E., \& Büyüksağnak, Y. B. (2021). Rusya Federasyonu ve Amerika Birleșik Devletleri'nin Arktik Bölgesi'ndeki uyuşmazlık konularına yönelik İngiliz Okulu Perspektifi'nden bir analiz. Journal of Human Sciences, 18(1), 76-93. doi:10.14687/jhs.v18i1.6094

Bununla birlikte bu doküman, tüm Arktik Bölgesi’nden ziyade sadece RF’nin Arktik Bölgesi'ndeki topraklarını kapsadığı için RF’nin Arktik doktrininin tamamını yansıtmadığı dikkatlerden kaçırılmamalıdır. Söz konusu dokümanda savunmadan ziyade ekonomik ve çevresel konulara vurgu yapılmıştır.

13 Mart 2015 tarihinde yayımlanan ABD'nin yenilenen Deniz Stratejisi ve NATO'nun doğuya doğru genişleme stratejisine karşıllk olarak Temmuz 2015'de Arktik doktrinini güncelleyerek; Kırım ve Arktik Okyanusu'nda Rus donanma varliğının artırılması ve nükleer buzkıran gemi filosunun genişletilmesi kararı yer almıştır. Diğer yandan 2000’li yıllarda Arktik jeopolitiği ve ekonomisinin küresel ısınma ve iklim değişikliği tartışmaları ile şekillendiği söylenebilir. 2016 yllında yayımlanan Strateji Belgesi'yle güncellenen doktrine göre:

- Arktik Bölgesi, RF’nin barışı, istikrarı ve yapıcı uluslararası işbirliklerini desteklemesi gereken bir bölgedir.

- Bölgeye yönelik her türlü siyasi ve askeri çatışma girişimlerine sert bir şekilde karşıllk verilecektir.

- Bölgede eşitlikçi ve karşıllklı yarar sağlayan uluslararası iş birliğinin geliştirilmesine öncelik verilmelidir (McDaniel, 2017).

Yeni doktrinde 4 fonksiyonel ve 6 bölgesel alan bulunmaktadır. RF'nin Denizcilik Doktrini'nde kendi deniz yetki alanları dışında Atlantik Okyanusu, Arktik Okyanusu, Pasifik Okyanusu, Hint Okyanusu ve Hazar Denizi bölgelerinde çıkarları olduğuna dair vurguya yer vermesi ciddi eleştirilere yol açmıstır (Parnemo, 2019). Dikkati çeken bir başka gelişme ise ÇHC ve Hint Donanmalarıyla yakın iş birliğinin hedeflenmesidir. 6 Mart 2020 tarihinde yayımlanan "2035 ve Temel İlkeler" isimli strateji dokümanında ise başta Kuzey Deniz Yolu olmak üzere deniz ticaret yolları ve ekonomik işbirliklerine vurgu yapılmıştır (Klimenko, 2020).

Diğer yandan 26 Ocak 2018 tarihinde yayımlanan "Çin Arktik Politikası" başlıklı Beyaz. Kitap'ta ÇHC'nin kendisini 'Arktik'e Yakın Devlet' (Near Arctic State) ${ }^{5}$ olarak tanımlaması, bölgeye yönelik ilgisinin sadece ekonomik nedenlerden kaynaklanmayıp 'Başlıca Sorumlu Ülke' (Responsible Major Country) sıfatıyla bölge politikalarında yer alacağına dair beyanları (Çin Halk Konseyi, 2018) büyük dikkat çekmiştir (DOD, 2019). 2018 yılında dünyanın en büyük ihracatçısı olarak öne çıkan ÇHC'nin, 2020 yılında petrol bakımından \%75 oranında dış kaynaklara bağımlı olduğu kayıtlara geçmiştir (The Maritime Executive, 2018). Petrol ihtiyacını kendi iç kaynaklarından yeteri kadar temin edemeyen ÇHC, 1990’lı y1llarda RF ile enerji iş birliği konusunda görüşmelere başlamıştır. 2009 yllında Moskova merkezli Rosneft şirketi ile Pekin merkezli ÇHC Ulusal Petrol Şirketi (CNPC) 25 milyar dolarlık (300 milyon tonluk petrole karşılık) bir anlaşma imzalamışlardır (Jakobson, 2010). 2013 yilına gelindiğinde Rosneft ve Sinopec arasında 2014 yilından itibaren 10 y1 boyunca 100 milyon tonluk petrol ihracatına yönelik bir mutabakat anlaşması imzalanmış ve böylelikle Rosneft'in ÇHC'ye ihracatı iki katına çıkarılmıştır (Rosneft, 2013).

Arktik Okyanusu'nda gemilerin seyir yapmasına uygun rotalar ve bu rotalara yönelik altyapının geliştirilmesi ve erimekte olan deniz buzları nedeniyle yıl içinde seyir şartlarına elverişli dönemin uzaması, ÇHC’nin deniz taşımacıllı̆ı planını daha da zenginleştirdiği gibi güzergâh boyunca yer alan devletlerin ve bölgelerin ekonomik ve ticari kalkınmalarının önünü açmıştır. Ayrıca Kuşak ve Yol Girişimi’ne ilave olarak ilan ettiği Kutup İpek Yolu Stratejisi, henüz geliştirilme safhasında olmakla birlikte söz konusu yolun bir kısmında Kuzey Deniz Yolu'nu kullanma planının, RF ve ÇHC arasındaki ticari iş birliklerine hız kazandıracağı ve ÇHC’nin üçüncü aktör olarak bölge

\footnotetext{
5Türkçe literatürde "Near Arctic State" ifadesinin "Yakın Arktik Devlet" olarak çevirisi kullanılmakla birlikte "Arktik'e Yakın Devlet” şeklinde bir ifadenin Çin'in kendisini bölgede yer almak isteyen bir aktör olarak görerek coğrafi, ekonomik ve siyasi açılardan bölgeye yakın olduğunu göstermeye çalıştı̆̆, bu nedenle okuyucun anlamı daha iyi kavrayabileceği düşünüldüğü için böyle bir çeviri tercih edilmiştir.
} 
Caymaz, E., \& Büyüksağnak, Y. B. (2021). Rusya Federasyonu ve Amerika Birleșik Devletleri'nin Arktik Bölgesi'ndeki uyuşmazlık konularına yönelik İngiliz Okulu Perspektifi'nden bir analiz. Journal of Human Sciences, 18(1), 76-93. doi:10.14687/ihs.v18i1.6094

hâkimiyet mücadelesinde aktif olarak yer alacağ1 öngörülmektedir (Lanteigne, 2016; Jakobson, 2010).

Bir başka çalışmada yer verilen kapsamlı analize göre ÇHC’li yetkililer; sularının açık deniz ve uluslararası sular olarak kabul edildiği, seyir serbestliğinin hâkim olduğu, doğal kaynak arama ve çevresel araştırma firsatlarından herkesin yararlanabildiği bir Arktik Bölgesi hedeflemektedir (Brady, 2014). Jakobson ve Peng (2012) tarafindan gerçekleştirilen güncel bir çalışmada ÇHC'nin Arktik ilgisinin gerçekçi olduğu ve Kanada için bölgedeki iş birliğini artırmaya yönelik iyi bir fırsat sunacağı belirtilmektedir. Söz konusu çalışmaya göre ÇHC'nin Arktik politikaları henüz olgunlaşma dönemindedir ve endişe verici değildir. ÇHC'nin, nükleer güçle çalışmayan dünyanın en büyük (163 $\mathrm{m}$ boyunda ve 21.000 ton deplasmana sahip) buzkıran gemisi 'Xue Long'un (Kar Ejderhası) beşinci kez gerçekleştirdiği Arktik geçiş seyrinde ilk defa Kuzey Deniz Yolu'nu kullanması ve nükleer buzkıran inşasına başlamasına paralel olarak Hong, bilhassa deniz ticareti açısından ÇHC'nin, Arktik bölge devletleri ile bölge dışındaki devletler arasında iş birliğini artıran kilit bir aktör olacağını ileri sürmüştür (Hong, 2012). Chen (2012) ise Çin'in Arktik stratejisinin, esas itibarryla grand stratejisinin bir bileşeni olan deniz stratejisinin devamı olduğu ve bu nedenle Arktik'e yönelik nihai hedefinin bilinemeyeceğine yönelik endişesini dile getirmiştir.

Bununla birlikte ÇHC'nin kendisini Arktik'e yakın devlet olarak ilân ederek Rusya ile ekonomik iş birliği ve bölgeye yönelik yatırımlar yapması, ABD tarafindan askeri bir tehdit olarak algılanmaktadır. Arktik Bölgesi'nde barışı tesis etmek ve çevre konularında iş birliği sağlamak amacıyla kurulan ve kurulduğu günden bu yana güvenlik tartısmalanının gündeme alınmadığı Arktik Konseyi'nin 2019 yılı toplantısında ilk defa ABD girişimiyle bölge güvenliği konusu gündeme taşınarak, Konsey'in kuruluş misyonunun dışında bir toplantı gerçekleştirilmiştir. ABD Dışişleri Bakanı M. Pompeo'nun, ÇHC ve RF'nin Arktik Bölgesi'ndeki rolü ve niyetlerine karşı çıkan sert bir üslupla eleştirilerde bulunması; ÇHC’nin kendisine biçtiği ‘Arktik'e Yakın Devlet' kimliğinin geçersiz olduğunu belirterek, Arktik Okyanusu'nun Güney Çin Denizi’ne dönüşmesine izin verilmeyeceğini dile getirmesi (Pompeo, 2019) bilhassa dikkat çekicidir.

ÇHC’nin Arktik Bölgesi’ne yönelik ilgisi, özellikle ABD ve RF arasındaki yoğun güç rekabeti ile $\mathrm{ABD}$ ve $\mathrm{ÇHC}$ arasında süregelen güç geçişi, Arktik Bölgesi’nde geleneksel güvenlik sorunlarına geri dönüss olarak ifade edilmektedir. Konuya ilişkin literatürde kelime seçimleri bilhassa dikkat çekicidir. Arktik Bölgesi'nde ABD ile RF arasındaki uyuşmazlıklar için 'power competition' (güç mücadelesi) ifadesi kullanılırken, ABD ile ÇHC arasındaki uyuşmazlıklar için 'power transition' (güç geçişi) ifadesi kullanılmıştır (Kopra, 2020). Bununla birlikte ÇHC'nin Arktik Bölgesi'ndeki bilimsel, ekonomik ve ticari faaliyetleri uluslararası hukuk kuralları bağlamında meşrudur. ABD'nin söz konusu faaliyetlere yönelik herhangi bir engellemede bulunması hukuki olmadığ gibi benzer bir üslupla söylemlerine devam etmesi uluslararası toplum nezdinde "saldırgan" olarak alg1lanmasına neden olmuştur (Chorush, 2020).

2020 y1lında gerçekleştirilen bir başka güncel bir araşturmaya göre ise ÇHC'yi Arktik Bölge ilişkilerinden uzak tutmaya çalışmak yasal, mantıklı veya uygulanabilir değildir. Günümüzde ÇHC'nin Arktik Bölgesi'ndeki gücü ekonomik yatırımlarından gelse de önümüzdeki dönemde Arktik Bölgesi'ne yönelik politika tartışmalarına katılım ve politikaları yönlendirme niyeti açıktır (Sun, 2020). Diğer yandan ÇHC'nin Arktik Bölgesi'ndeki yatırımların sadece ticari amaçlarla gerçekleştirildiği, her ne kadar RF'nin Arktik projelerine partner olarak katılım sağlasa da iki devlet arasında politik bir iş birliği bulunmadığ1 yönünde görüş belirten çalışmalar da bulunmaktadır (Buchanan, 2020). Çalışmanın bundan sonraki bölümünde Arktik Bölgesi'ndeki en önemli aktörlerden biri olan ABD'nin Arktik doktrinine daha detaylı olarak yer verilecektir. 
Caymaz, E., \& Büyüksağnak, Y. B. (2021). Rusya Federasyonu ve Amerika Birleșik Devletleri'nin Arktik Bölgesi'ndeki uyuşmazlık konularına yönelik İngiliz Okulu Perspektifi'nden bir analiz. Journal of Human Sciences, 18(1), 76-93. doi:10.14687/ihs.v18i1.6094

\section{Amerika Birleşik Devletleri'nin Arktik Doktrini}

ABD, 153 yıldır bir Arktik ülkesidir. En çok kabul gören tanımılla 66 33' 44" Kuzey enleminin ${ }^{6}$ kuzeyinde kalan ve Arktik Dairesi olarak bilinen bölgede toprağ olan 8 ülkeden birisidir. Ayrıca, Arktik Okyanusu bitişiğindeki denizlere kıyısı bulunan beş ülkeden biri olan ABD, bu özelliğini 1867 yllında Alaska’yı, o zamanki değeriyle, 7.2 milyon dolara Rusya'dan satın alarak gerçekleştirdiği stratejik hamleye borçludur (Pompeo, 2019). Alaska Satış Antlaşması'nın ABD'nin Arktik'e yönelik ilk politik belgesi olduğu söylenebilir.

ABD, sonradan parçası olduğu bölgeye karşı ilgisini daima en üst seviyede göstermiştir. 1971 yılında 'gizli' gizlilik derecesiyle yayımlanan memorandumda ABD Başkanı Richard Nixon, Ulusal Güvenlik Konseyi'nin tavsiyesine uyarak Arktik politikası ve uygulamalarına yönelik organizasyonel düzenlemelere ilişkin, çevreye karşı olan olumsuz etkilerin en aza indirilmesi ilkesi doğrultusunda Arktik Bölgesi'nin gelişiminin desteklenmesine karar vermiştir (National Security Council, 1971). Böylece Kuzey Kutup Bölgesi’nde karşlıklı çıkarlara dayalı uluslararası iş birliğinin teşvik edilmesi ve aynı zamanda açık denizlerin ve üzerindeki hava sahasının serbestliği prensibi dâhil bölgedeki temel güvenlik çıarlarının korunması hedeflenmiştir.

ABD tarihinde ilk defa başkan Nixon tarafindan diğer devletlerle bilimsel araştırmalar ve keşifler yapılması, kaynakların geliştirilmesi ve bilimsel ve teknik verilerin değişimi gibi alanlarda iş birliğinin artırılmasi; ABD'nin Kuzey Kutup Bölgesi'nde yerleşme ve faaliyet gösterme imkân ve kabiliyetlerini geliştirilmesi, bölge şartlarının daha iyi anlaşılabilmesi ve uluslararası iş birliğinin sağlanması için bir çerçeve oluşturulması amacıyla plan ve projeler geliştirilmesi ve detaylı programlar hazırlanması direktifi verilmiştir. Nixon yönetimi zamanında bir Arktik Antlaşma Sistemi kurulması için "Northlands Compact" ismi verilen bir girişimde bulunulmuştur. Ancak 1973 tarihli 2020 numaralı Ulusal Güvenlik Kararı Bildirisi’nde dönemin Dışişleri Bakanı Henry Kissinger’ın “Başkan Sovyetler Birliği, Kanada ve Arktik'te çlkar olan diğer devletlerle çok uluslu bir Northlands ve Arktik Işbirliği sürecinin tesis edilmesi ve bu amaçla ABD tarafindan uluslararası bir konferansin toplanmasim şu an için arzu etmemektedir" şeklindeki ifadeleriyle gerçekleştirilemeyen bir yaklaşım olarak kaldığı anlaşılmaktadır (National Security Council, 1973).

1983 yılına gelindiğinde Ronald Reagan tarafindan yayımlanan ABD Arktik Politikası başlıklı direktifte, Arktik Bölgesi’nde açık denizlerin ve üzerindeki hava sahasının serbestliği prensibi dâhil, ABD'nin temel güvenlik çıkarlarının korunması, bölgenin gelişimini ve olumsuz çevresel etkilerin azaltılması, bölge ile ilgili bilimsel çalışmaların desteklenmesi ve bölgede karşılıklı yarar sağlayan uluslararası işbirlikleri oluşturması amaçlanmıştır (National Security Council, 1983). 1984 tarihli Arktik Araştırma ve Politika Yasası ile ABD Başkanı'na bir Arktik Araştırma Komisyonu kurma emri verilmiştir. Buna uygun olarak Ronald Reagan'ın 1985 yılı başında imzaladığı yürütme emriyle ABD'nin Arktik'e ilişkin ulusal araştırma politikalarını geliştirip tavsiyelerde bulunan komisyon (USARC) kurulmuştur?.

1994 yllına gelindiğinde ise Bill Clinton tarafindan yayımlanan ve daha kapsamlı bir çerçeve sunan Başkanlık Kararı Direktifi'nde (PDD/NSC-26) Arktik Bölgesi'nde ABD için 6 temel hedef belirlenmiştir. Bu hedefler; Soğuk Savaş sonrası ulusal güvenlik ve savunma ihtiyaçlarının karşılanması; çevre ve biyolojik kaynakların korunması; doğal kaynak yönetimi ve ekonomik

\footnotetext{
${ }^{6}$ Arktik Çemberi'nin konumu sabit değildir ve șu anda Ekvatorun $66^{\circ} 33^{\prime} 48.2$ " kuzeyinde var olduğu düșünülen hayali bir hat üzerindedir. Enlemi, Ay'ın yörüngesinden kaynaklanan gelgit çekim kuvveti nedeniyle 41.000 yıllık süre içinde $2^{\circ}$ 'den fazla bir marjda dalgalanan Dünya'nın eksenel eğimine bağlıdır. Çember hali hazırda, yılda yaklaşık olarak $15 \mathrm{~m}$. kuzeye doğru kaymaktadır.

${ }^{7}$ Yedi kişiden oluşan komisyonun görevleri şu şekilde belirlenmiştir: (1) Karma bir ulusal Arktik araştırma politikası oluşturmak ve bu politikayı uygulamak için bir program yapmak; (2) Araştırmalarda Federal Hükümet ile eyalet ve yerel yönetimler arasındaki işbirliğini teşvik etmek; (3) Federal araştırma programlarının koordinasyonundaki gelişmeleri gözden geçirmek ve önerilerde bulunmak; (4) Araştırmalar için lojistik planlamanın ve desteğin geliştirilmesi için yöntemler önermek; (5) İlgili kamu ve özel kurumlar arasında Arktik hakkında etkili paylaşım ve bilginin yayılmasını geliştirmek için yöntemler önermek; (6) Arktik araştırma politikasının oluşturulmasında Alaska Valisi ve eyalet kurumları ile işbirliği yapmaktır.
} 
Caymaz, E., \& Büyüksağnak, Y. B. (2021). Rusya Federasyonu ve Amerika Birleșik Devletleri'nin Arktik Bölgesi'ndeki uyuşmazlık konularına yönelik İngiliz Okulu Perspektifi'nden bir analiz. Journal of Human Sciences, 18(1), 76-93. doi:10.14687/jhs.v18i1.6094

gelişmenin çevresel olarak sürdürülebilirliğinin güvence altına alınması; sekiz Arktik devletinin arasında iş birliği için kurumların güçlendirilmesi; bölgedeki yerli halkların kendilerini etkileyecek kararlarda sürece dâhil edilmesi ve yerel, bölgesel ve küresel çevre konularında bilimsel izleme ve araştırmaların geliştirilmesidir. Soğuk Savaş'ın sona ermesinin ardından gerilimin büyük ölçüde azaldığı ve ABD'nin Arktik politikasında önemli bir değişikliğe imkân sağlandığı, böylece RF ile oluşan yeni açıklık ve iş birliği atmosferi içinde sekiz Arktik devleti arasında çevre koruma, çevresel olarak sürdürülebilir kalkınma, yerli halkların endişeleri ve bilimsel araştırma konularında eşi görülmemiş fırsatların ortaya çıttı̆ı belirtilmiştir. Ayrıca bu alanlarda gerçekleştirilecek iş birliğinin geleneksel tehditlerin yeniden canlanması riskini de azaltmaya yardımcı olacağı vurgulanmıştır. Bu bilgilere ek olarak, 1982 BMDHS ile geleneksel hukuk prensipleri çerçevesinde gemi ve uçaklar için açık denizlerin ve üzerindeki hava sahasının serbestliği prensibi tekrar belirtilmiştir (White House, 1994). Arktik Bölgesi’nde oluşan kirlilikten büyük oranda sorumlu tutulan ve birçok biyolojik kaynağa ev sahibi olan RF ile sürdürülen ikili ilisskiler sayesinde bölgede çevrenin korunması için firsatlar yaratıldığ1, bilimsel alanda uzmanlığ1 olmakla birlikte RF’nin bilimsel araştırmalar için ayırdığ1 ekonomik kaynağın sınırlı olduğunun belirtilmesi dikkati çeken bir başka husustur.

George Bush tarafindan 2009 yılında yayımlanan Ulusal Güvenlik / Ülke Güvenliği Başkanlık Direktifi'nde (NSPD-66/HSPD-25) ise daha önce Bill Clinton imzasiyla yayımlanan 26 numaralı Direktif teki Antarktika'ya ilişkin maddelere dokunulmazken Arktik Bölgesi ile ilgili politikada bazı değişikliklere gidildiği anlaşılmaktadır. Bunda Soğuk Savaş’ın sona ermesinin üzerinden geçen zaman ve RF'nin uluslararası arenada yeniden kendini gösterme ve Arktik'teki faaliyetlerini artırma çabalarının etkili olduğu söylenebilir. Belirlenen temel hedeflerde Soğuk Savaş vurgusu yapılmadan ulusal ve ülke güvenliği ihtiyaçlarının karşılanması gerektiği belirtilmiş, diğer maddeler 15 yıl önceki hedeflerle aynen muhafaza edilmiştir (White House, 2009). Direktif te ayrıca, Arktik'te ABD'ye karş1 gerçekleştirilebilecek olası terörizm faaliyetlerine karşı dikkatli olunması gerektiği, bölgede insani faaliyetlerin artmakta olduğu ve bu artışın gelecekte de devam etmesinin beklendiği, açık deniz serbestliği prensibinin ABD için milli öncelik olduğu ve bölgede yer alan boğazlardan transit geçiş rejiminin uygulanması gerektiği hususlarına vurgu yapılmıştır. Arktik Konseyi'nin mevcut haliyle korunmasından yana olan ABD'nin bununla birlikte, Konsey'in genel yetkisi ile tutarlı olduğu ölçüde, yardımcı organlarının takviye edilmesi veya operasyonel değişiklikler de dâhil olmak üzere Konsey yapısını güncellemeye açık olduğunu ifade etmiştir.

ABD'nin 44. başkanı Barack Obama'nın imzasıyla yayımlanan 10 Mayıs 2013 tarihli Arktik Bölge Ulusal Strateji Belgesi’nin tamamı incelendiğinde bölgeye yaklaşımın daha çok çevre boyutunu öne çıkararak ve yumuşak bir üslupla kaleme alındığı görülmektedir. Gezegenimizin keşfedilen en son bölgesi ve barışçıl, istikrarlı ve çatışmalardan uzak bir alanı olarak görülen Arktik'te, küresel ısınma ve iklim değissikliği nedeniyle yaşanan büyük değişim sonrasında ortaya çıkan ekonomik firsatlar nedeniyle doğal olarak dikkatlerin bölgeye çevrildiği, bununla birlikte bu eşsiz ve değerli çevrenin korunması ve muhafaza edilmesi ihtiyacı bulunduğu belirtilmektedir. Söz konusu stratejiye göre ABD ve bölgedeki müttefik ve ortakları, bu güven ve iş birliği ruhunu hem uluslararası alanda hem de kendi ülkelerinde sürdürmeye çalışmaktadırlar. Belirlenen stratejinin üç eksen üzerine inşa edildiği, bu kapsamda bölgedeki tüm faaliyetlerin uluslararası hukuka uygun olarak icra edilerek ABD'nin güvenlik çıkarlarının geliştirilmesi; çevre ve kaynakların korunmaya devam edilmesi ve uluslararası iş birliğinin güçlendirilmesinin benimsendiği anlaşılmaktadır. Ayrıca, BMDHS'yi imzalayan ancak henüz onaylamayan ABD'nin bahse konu sözleşmeye katılımı üzerinde çalışlacağı belirtilmiştir (White House, 2013).

2019 Haziran ayında ABD Savunma Bakanlığ1 tarafindan hazırlanarak Kongre'ye sunulan Arktik Bölge Strateji Belgesi’nde dikkati çeken en önemli husus, uzun vadede, ABD güvenliği ve refahının önündeki en temel zorluğun ÇHC ve RF ile rekabet olduğunun belirtilmiş olmasıdır ${ }^{8} .2018$

${ }^{8}$ Strateji belgesinde Arktik Bölge, ABD’nin 1984 tarihli kanununa uygun olarak şu şekilde tanımlanmaktadır: Arktik çember kuzeyindeki ABD ve yabancı ülkelere ait topraklar; Alaska içindeki Porcupine, Yukon ve Kuskokwim nehirlerinin 
Caymaz, E., \& Büyüksağnak, Y. B. (2021). Rusya Federasyonu ve Amerika Birleșik Devletleri'nin Arktik Bölgesi'ndeki uyuşmazlık konularına yönelik İngiliz Okulu Perspektifi'nden bir analiz. Journal of Human Sciences, 18(1), 76-93. doi:10.14687/jhs.v18i1.6094

yılında yayımlanan ABD Ulusal Savunma Stratejisi'ndeki (NDS) önceliklere göre hazırlandığ1 vurgulanan belgede Arktik Bölgesi için arzu edilen nihai hedef, bölgenin ABD ulusal çıkarlarının ve anavatanının korunduğu ve ulusların ortak sorunları çözmek için iş birliği içinde çalıştı̆̆ güvenli ve istikrarlı bir bölge olarak ortaya konmaktadır. Bu strateji belgesinde, Arktik güvenlik ortamı, ABD ulusal güvenlik çıkarlarına yönelik riskler, hedefler ve bu hedeflere ulaşmak için gerekli stratejik yaklaşımlar değerlendirilmiştir (DoD, 2019).

Güvenli ve istikrarlı bir Arktik Bölgesi, ABD açısından faydalı olmakla birlikte Arktik devletlerinin ulusal egemenliğe saygılı olmalarını ve paylaşılan zorlukları ele almak için yapıcı katılımlarını yansıtan kurallara dayalı bir düzen gerektirmektedir. Bu kurallara dayalı düzende benzer ulusal çıkarlara sahip bölgedeki NATO müttefiki ve partner devletlerin varllğ1 ABD'nin en büyük stratejik avantajını oluşturmaktadır. Bu avantaj Arktik stratejisinin temel taşını oluşturmakta, bölgesel güvenliğe yönelik ortak yaklaşımı güçlendirmekte ve ÇHC ve RF'nin mevcut kurallara dayalı düzeni tek taraflı değiştirme çabalarını caydırmaya yardımcı olmaktadır (DoD, 2019).

ABD Ulusal Savunma Stratejisi'nde belirlenen hedef ve öncelikler Savunma Bakanliğı'nın (DoD) Kuzey Kutup Bölgesi'ne yönelik stratejik yaklaşımına rehberlik etmektedir. Buna göre DoD, NDS tarafindan tanımlanan ana sorunu ele alma çabalarına öncelik vermelidir. Burada kastedilen sorunlar oluşturulacak Müşterek Kuvvet'in ÇHC ve RF'ye karşı aşınan rekabet gücü ve Hint-Pasifik ve Avrupa'daki bölgesel güç dengelerinin lehe çevrilmesine yönelik talimatıdır. Daha güçlü, dayanıklı, çevik ve hazır bir Müşterek Kuvvet geliştirmek, sadece stratejik rekabetin bu önemli bölgeleri için değil, küresel olarak da rekabet avantajını sürdürmesini sağlayacaktır. Arktik Bölgesi için güvenilir bir caydırıcılık sağlamak için DoD'nin, Arktik'in gelecekteki operasyonlar için jeostratejik önemini anlamasını ve şekillendirmesini, ayrıca hem tek başına hem de diğer devletlerle iş birliği içinde Arktik Bölgesi’ndeki her türlü gelişmeye bağlı olarak etkili bir şekilde yanıt vermesini gerektirmektedir. Arktik Bölgesi için nihai hedefin elde edilebilmesi için DoD'nin stratejik olarak yapması gereken üç yaklaşım şu şekilde belirlenmiştir:

- Kuzey Kutup Bölgesi'ne yönelik farkındalık oluşturmak,

- Kuzey Kutup Bölgesi'nde faaliyet ve operasyonları artırmak,

- Kuzey Kutup Bölgesi’nde kurallara dayalı bir düzeni güçlendirmek.

Son strateji belgesinin yayımlanmasının hemen ardından ABD Başkanı Donald Trump, dünyanın en büyük adası olan ve yüzde sekseni buzullarla kaplı Grönland Adası'nı satın alma olasılığıyla ilgilendiğini açıklamıştır. Yaptığı açıklamada; adanın halen Danimarka'ya ait ve Danimarka'nın bir NATO üyesi olarak ABD'nin iyi bir müttefiki olduğunu, öte yandan dünyanın birçok ülkesi gibi ABD’nin Danimarka'yı da koruduğunu ve yardım ettiğini ve korumaya devam edeceğini belirtmiştir. Bununla birlikte adanın Danimarka'ya büyük bir mali yük getirdiğini ve yıllık 700 milyon dolarlık kaybı olduğunu, Kraliçe'nin daveti üzerine Danimarka'ya yapacağı ziyarette bu konunun bir numaralı gündem maddesi olmasa da konuşulabileceğini ifade etmesi büyük eleştirilere yol açmışur (Breum, 2019).

2015 yllında Arktik girişimlerinde Koordinasyonu Artırma ile ilgili Yürütme Emri (Executive Order for Enhancing Coordination of Arctic Efforts) ile nihaî Arktik doktrinini şekillendiren ABD, başta RF ve Kanada olmak üzere çeşitli Arktik devletleri ile kıta sahanlığı konularında uyuşmazlıklar yaşamaktadır. BMDHS'yi imzaladığı halde halen senato onayını alamayan ABD'nin hak talepleri de yasal bağlamda karşlıksız kalmaktadır. RF'nin NSR'yi kullanacak askeri gemilere yönelik 45 gün önceden bildirimde bulunma zorunluluğuna cevaben 2019 yllında "Arktik Okyanusu hiç kimsenin gölü değildir" (Lanteigne, 2019) beyanında bulunan ABD, çevre ve ekonomik iş birliklerinin tartışıldığı Arktik Konseyi'nin 2019 yılı toplantısında Arktik Bölgesi'nde RF ve artan ÇHC varlığına

oluşturduğu sınırın kuzey ve batısındaki ABD toprakları; Arktik Okyanusu, Beaufort Denizi, Bering Denizi ve Çukçi Denizi dahil tüm bitişik denizler ve Aleut Adaları zinciri. 
Caymaz, E., \& Büyüksağnak, Y. B. (2021). Rusya Federasyonu ve Amerika Birleșik Devletleri'nin Arktik Bölgesi'ndeki uyuşmazlık konularına yönelik İngiliz Okulu Perspektifi'nden bir analiz. Journal of Human Sciences, 18(1), 76-93. doi:10.14687/ihs.v18i1.6094

yönelik “Acil Güvenlik Sorunu” (Pompeo, 2019) tanımlamasında bulunarak Konsey tarihinde ilk defa güvenlik sorunları gündeme getirmiştir

\section{Yöntem}

$\mathrm{Bu}$ çalışma kapsamında nitel araştırma yöntemlerinden doküman inceleme yöntemi kullanılmıştur. Öncelikle Arktik güvenliği, ABD Arktik doktrini, İngiliz Okulu, RF Arktik doktrini ve uyuşmazlık analizi kavramlarına yönelik detaylı bir literatür taraması yapılarak Türkçe ve İngilizce dillerinde yayımlanan tüm kitap, makale ve resmi dokümanlar taramaya dahil edilmiştir. Taramaya dahil edilen kaynaklar kapsamında ABD ve RF arasındaki Arktik Bölgesi'ne yönelik uyuşmazlık konuları, İngiliz Okulu'nun sunduğu tarihsel perspektifle doküman analizi yöntemi kullanılarak analiz edilmiş ve elde edilen bulgular sonuç bölümünde tartışılmıştr.

\section{Bulgular \\ Arktik Bölgesi'nde RF-ABD Arasındaki Uyuşmazlık Alanlarına İngiliz Okulu Perspektifinden Bir Bakış}

Arktik devletleri arasındaki en önemli anlaşmazlık konusu bölgenin genelinde var olan kıta sahanlığı sorunudur. ABD ve RF arasındaki temel uyuşmazlık alanları ise Bering Denizi'ndeki deniz sınır hattının nereden geçeceği ve Kuzey Deniz Yolu'nun kullanımına ilişkin konulardadır (Byers, 2009).

Arktik Bölgesi'nde egemenlik taleplerine yasal dayanak sağlayan BMDHS'de, açık denizlerde hiçbir devletin egemenlik iddia edemeyeceği ve kıyısı bulunsun ya da bulunmasın açık denizlerin her devlete açık olacağı belirtilmiştir. Açık denizlerin her devlet için hangi serbestlikleri getireceği alı maddede sıralanmıştır. Bunlar:

a) Seyrüsefer serbestisi $(87 / 1)$

b) Açık deniz üzerinden uçma serbestisi,

c) Denizaltı kabloları ve petrol boruları döşeme serbestisi,

d) Sunî adalar ve uluslararası hukukun izin verdiği diğer tesisleri inşa etme serbestisi,

e) Balık avlama serbestisi,

f) Bilimsel araştırma serbestisidir (Özman, 1984).

Bununla birlikte RF, ABD'nin Arktik Okyanusu'ndaki münhasır ekonomik bölgesine araştırma yapmak için girişine 1998 yılından beri izin vermemektedir (Moore, 2004). Rusya 12 Mart 1997 tarihinde BMDHS'yi onayladıktan sonra sözleşmenin 246. Maddesi'nin 1. ve 2. Bentlerine göre kıyıdaş devletlere sunduğu egemenlik haklarından yararlanarak, her ne kadar 3. Bent sebepsiz yere reddetmeler için bir engel teşkil etse de Arktik'teki yabancı devletlerin faaliyetlerine izin vermemektedir. Yine aynı sözleşmenin 234. Maddesi'ne göre; "bu§la kaph deniqler ile sınırl olmak üzere, kıyı devletlerine çıkaracağı kanunlar ve yönetmeliklerle münhasir ekonomike bölgelerinin içindeki insani eylemleri, cevreyi koruma amacyla kontrol etme ve simirlama yapma bak.ke tanumıstur. Bu madde ile birlikte k.inudas devlete, gemilerden kaynaklanan kirlilikleri önlemek, azaltmak ya da kontrol etmek için kanun ya da yönetmelik çlkarma bakke verilmektedir" (Özman, 1984).

RF'nin bu duruma karşı makul bir neden göstermiyor oluşu ise tartışmalı bir husustur. Bununla birlikte BMDHS'nin 77. Maddesi konuyla alakalı bir çelişki oluşturmaktadır. 77. Madde'nin 2. Bendi kıta sahanlığına ilişkin tüm izin ve onayları kıyıdaş devletin egemenlik alanı içinde kabul etmektedir. ABD’nin, Rusya'nın onayını almadıkça belirtilen faaliyetlerde bulunması uluslararası hukuk açısından uygun görünmemektedir.

Bering Denizi sınır hattının belirlenmesine yönelik uyuşmazlıkta hattın belirlenmesi için 1976 yılında görüşmeler yapılmış ancak kullanılan yöntem farklarından dolayı 15 bin deniz millik bir anlaşmazlık alanı oluşmuştur. 1990 yılında iki devlet arasında ortaya çıkan mutabakatla bir anlaşma imzalanması mümkün olmuştur. Bu anlaşma her ne kadar Rus Parlamentosu'nun alt kanadı 
Caymaz, E., \& Büyüksağnak, Y. B. (2021). Rusya Federasyonu ve Amerika Birleșik Devletleri'nin Arktik Bölgesi'ndeki uyuşmazlık konularına yönelik İngiliz Okulu Perspektifi'nden bir analiz. Journal of Human Sciences, 18(1), 76-93. doi:10.14687/jhs.v18i1.6094

Duma tarafindan onaylanmamış olsa da bu anlaşmaya aykırı fili bir gelişme de yaşanmamıştır (Gül, 2014).

RF ve ABD'nin Arktik politika, doktrin, strateji ve uyuşmazlık konularını ele alan güncel literatür incelendiğinde iki temel yaklaşımın olduğu görülmektedir. Bunlardan ilki, kaynakların paylaşımına yönelik uyuşmazlıkları ve olası askeri müdahaleleri konu eden realist bakış açısıyla yapılmış çalışmalardır. İkincisi ise mevcut iş birliği ve yönetişimi öne çıkararak vurgulayan ve sayıca daha az olan liberal bakış açısıyla yapılmış çalışmalardır. Uyuşmazlık boyutlarını realist bir bakış açısıyla irdeleyerek, iş birliği ve yönetişimle sentezleyebilen çalışma sayısı ise oldukça azdır (Ohnishi, 2014).

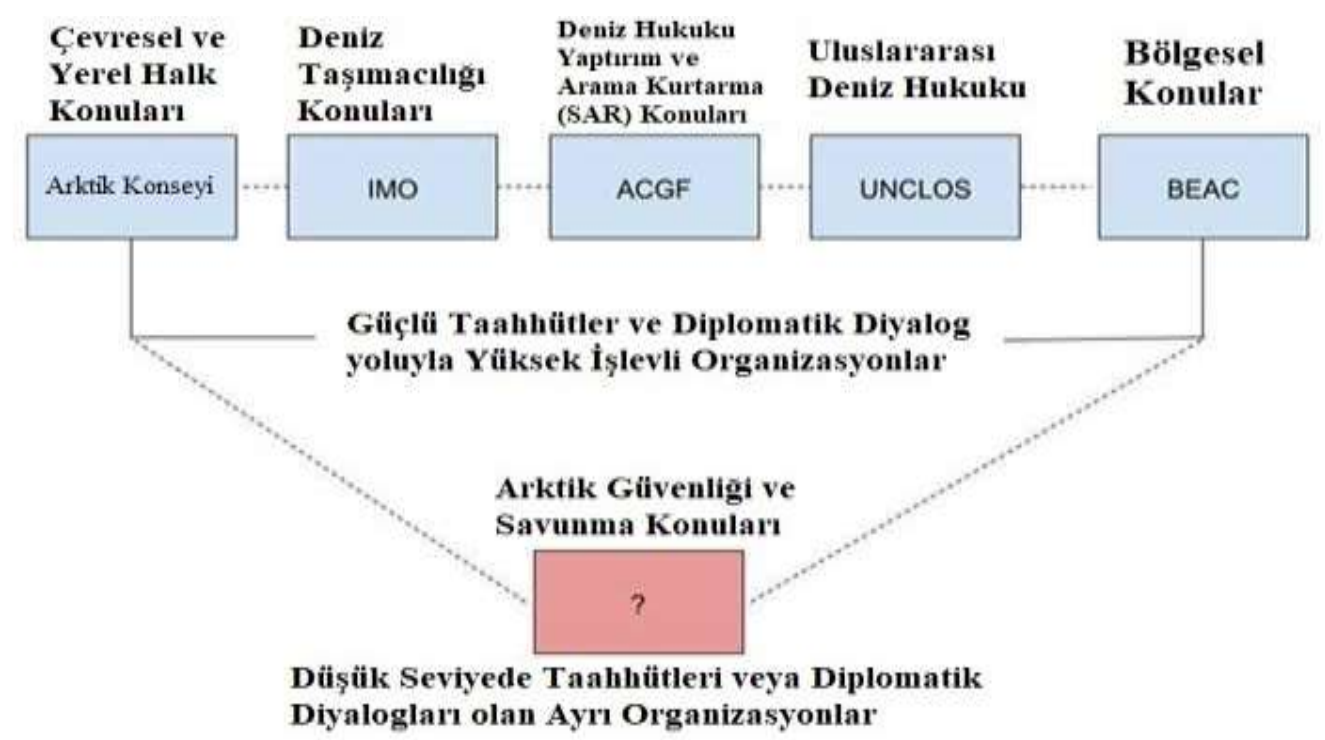

\section{Şekil-1. Arktik Bölgesi’ndeki Uluslararası Kurumların Görev, Yetki ve Sorumluluk Alanlar1}

Şekil-1'de Arktik Bölgesi'ndeki uluslararası kurumların görev, yetki ve sorumluluk alanlarına yer verilmiştir. Uluslararası deniz hukuku, bölgesel konular, arama kurtarma, çevresel konular ve bunlara yönelik muhtemel uyuşmazlıklar için çerçeve çizen yapılanmalar olmakla birlikte Arktik güvenliği ve savunma konularını düzenleyen herhangi bir yapının olmadığı görülmektedir. Diğer yandan mevcut güvenlik söyleminin sunduğu analizlerin büyük bir kısmı başta enerji güvenliği ve askeri konular olmak üzere, tekil ve doğrusal boyutlar üzerine odaklanmaktadır. Arktik Bölgesi'nin militarizasyonunun (askerileştirme) ötesinde güvenlik çalışmalarına, bilhassa deniz buzunun erimesiyle doğal kaynakların keşfinin daha kolay hale gelmesine ve 1sınan Arktik Bölgesi’nin deniz seviyesinde yükselmeye yol açmasının genel olarak dünya nüfusunun güvenliğinde oluşturacağı zafiyetlere odaklanan birçok Uİ çalışması bulunmaktadır. Ancak söz konusu çalışmalar bölgeye yönelik daha derinlikli bir anlayışı, dolayısıyla, güvenlik aktörleri arasındaki uyuşmazlıkların çözümünün yanı sıra iş birliği ve uzmanlık paylaşımını teşvik edebilecek çok disiplinli boyutlardan yoksundur (Jacobsen ve Herrmann, 2019).

$\mathrm{Bu}$ çalsşmada İngiliz Okulu perspektifinin seçilme sebebi, İngiliz Okulu'nun sistemik, toplumsal ve dünya toplumu düzeylerinin hepsinde tarihsel bir bakış açısıyla çok boyutu analizler yapılmasına imkân sağlayarak, bu tür çalışmalara yönelik uygun altyapıyı sunabilmesidir. Çalışmanın sonuç bölümünde bahsi geçen uyuşmazlık konularına yönelik İngiliz Okulu perspektifinden çözüm önerilerine yer verilecektir. 
Caymaz, E., \& Büyüksağnak, Y. B. (2021). Rusya Federasyonu ve Amerika Birleșik Devletleri'nin Arktik Bölgesi'ndeki uyuşmazlık konularına yönelik İngiliz Okulu Perspektifi'nden bir analiz. Journal of Human Sciences, 18(1), 76-93. doi:10.14687/ihs.v18i1.6094

\section{Sonuç ve Tartışma}

Küresel 1sınmanın etkilerinin çok daha fazla hissedildiği Arktik Bölgesi, geri çekilen buzullar ve eriyen deniz buzlanı nedeniyle özellikle 2000’li yllardan itibaren zengin yeraltı kaynakları ve alternatif deniz ticaret rotalarınınsağlayacağı ekonomik ve ticari potansiyeliyle uluslararası çevrelerin gündeminde ön sıralarda yer almıstır. ABD, Alaska kıyı uzunluğuna paralel olarak Rusya ve Kanada’ya göre daha küçük bir kıta sahanlığına ve dolayısıyla daha az talepte bulunma hakkına sahiptir. Bununla birlikte Arktik Bölgesi’ne yönelik mevcut resmi dokümanlardaki ifadelerine ilaveten ABD Eski Dışişleri Bakanı M. Pompeo'nun Arktik Konseyi'nin 2019 yll toplantısının hemen öncesinde Finlandiya'da yaptığı konuşma ve ABD'nin güç temelli yaklaşımı, aldığı eleștirilere rağmen bu yönde ilerleyeceğine dair sinyaller vermektedir. Grönland'ı satın almak isteyen ABD, bu topraklara sahip olması halinde; küresel ısınma ve iklim değişikliği nedeniyle son yıllarda jeopolitik açıdan önemi giderek artmakta olan Arktik Okyanusu'na Alaska dışında farklı bir coğrafyadan da kıyıdaş devlet konumu kazanacaktır. ABD'nin böylelikle bölgede Rusya'ya karşı dezavantajlı konumunu biraz olsun azaltmayı planladığ1 düşünülmektedir. Bu noktada kıta sahanlı̆ı ve münhasır ekonomik bölge gibi deniz yetki alanlarını arturarak hem Rusya'ya, hem de Kutup İpek Yolu Projesi vasıtasıyla bölgeye ve Grönland'a olan ilgisini açıkça gösteren ÇHC'ye karşı avantaj sağlamak istemesi dikkat çekicidir.

Diğer yandan bölge içinde sahip olduğu yüzölçümünün büyüklüğü ve nüfusu açısından kilit Arktik devlet olarak öne çıan RF, bölge ekonomisi bağlamında da büyük öneme sahiptir. ABD'nin Arktik stratejisi, bölgeye yönelik operasyonel yetenekleri ve uluslararası forumlardaki temsili diğer Arktik devletlerine kiyasla daha yavaş bir gelişim göstermişken, RF'nin BMDHS'ye ilk başvuran devlet olması, hak taleplerini uluslararası hukuk kurallarına uygun bir biçimde gündeme getirmesi, Arktik Konseyi nezdinde uluslararası toplumu güçlendirmeye yönelik vurguları ve ÇHC ile Arktik'te büyük çaplı ekonomik işbirliklerinde bulunması ABD'nin RF ve ÇHC'yi “tehdit” olarak değerlendirmesine neden olmuştur. Konuya yönelik literatür incelendiğinde, bu bilgilere paralel olarak, RF ve ÇHC'ye yönelik yayımlanan makale ve raporların genelinde salt realist bir bakış açısıyla, RF'nin Arktik Bölgesi'nde en uzun kıyı şeridine, dolayısıyla en fazla kıta sahanlığına sahip devlet olduğu gerçeğinin göz ardı edilerek, her iki devletin de tehdit olarak algilandığı ve bu doğrultuda değerlendirmelerde bulunduğu görülmektedir. Bu kapsamda bilhassa RF'nin Kuzey Deniz Yolu üzerinde yer alan tesislerini modernize etmesi ve yol boyunca artması beklenen seyir sayısını desteklemek amaciyla buzkıran filosunu çok daha güçlü hale getirerek yenilemesini bir güvenlik sorunu olarak gören değerlendirmelerin kapsamı dar ve yetersiz kalmaktadır. Bu bilgilere ek olarak iklim değişikliği, küreselleşme, kentleşme ve demografik değişimler, Arktik Bölgesi'ndeki kültürleri, ekonomileri ve sosyo-politik yapıları da hızla dönüştürmektedir. Bu nedenle dikkate değer bir hızla değişen Arktik Bölgesi'nde, öncelikli olarak güvenlik olmak üzere, Uİde sıklıkla kullanılan çeşitli kavramların ne anlama geldiğine dair kapsamlı araştırmalara ihtiyaç vardır. Ayrıca ÇHC'nin bölgeye yönelik artan nüfuzunu doğru değerlendirebilmek için daha eşgüdümlü ve çok yönlü bir yaklaşım gerekmektedir.

İngiliz Okulu'nun gerçekçilik, akılcılık ve devrimcilik geleneklerini sentezleyerek kapsamlı analizler sunan çerçevesi bu noktada önem kazanmaktadır. ABD, her ne kadar askeri güce yönelik projeksiyonların, ÇHC’yi Arktik Bölgesi'nden uzaklaştırmak için yeterli caydırıcıllğa sahip olduğu düşünse de güç temelli bu yaklaşımın yerini, günümüzde, bağlayıcılı̆̆ bulunan uluslararası kurallar almıştır. Küresel 1sınmaya yönelik sadece Arktik devletlerinin tedbir almaları yeterli olmadığı gibi bölgeye yönelik çevre politikaları geliştirmede sadece bu devletlerin oy hakkının olması da tartışmaya açık bir konudur. Diğer yandan ÇHC’nin dünyanın en fazla karbondioksit salımını yapan devleti olması, çevresel iş birliği amacıyla kurulan Arktik Konseyi'nin misyonuyla birebir uyuşmakta ve ÇHC'nin bölgeye yönelik bilimsel faaliyetleri için uluslararası toplum nezdinde de meşruiyet oluşturmaktadır. Başta ÇHC olmak üzere konseye gözlemci olarak katılım sağlayan diğer devletlerin, önümüzdeki yıllarda politika geliştirmede daha fazla söz ve oy hakkı olacağı değerlendirilmektedir.

Diğer yandan bölgeye yönelik hukuki düzenlemelere yön veren BMDHS'nin çelişki yaratan maddeleri her ne kadar devletler arası uyuşmazlıklara yol açsa da diyalog kurma ve uyuşmazlıkları çözümleme noktasında bölgede faaliyet gösteren uluslararası örgütlerin önemi ortaya çıkmaktadır. 
Caymaz, E., \& Büyüksağnak, Y. B. (2021). Rusya Federasyonu ve Amerika Birleșik Devletleri'nin Arktik Bölgesi'ndeki uyuşmazlık konularına yönelik İngiliz Okulu Perspektifi'nden bir analiz. Journal of Human Sciences, 18(1), 76-93. doi:10.14687/jhs.v18i1.6094

Arktik Bölgesi'ndeki iş birliği potansiyelinin geliştirilerek süreç içerisinde Gorbaçov’un hayal ettiği bir barış alanına dönüştürülebilmesi için başta kıyıdaş devletler olmak üzere uluslararası toplumun; salt küresel ısınma nedeniyle ortaya çıkan zengin enerji kaynaklarının ve yeni deniz ulaşım / ticaret yollarının sunduğu ticari ve ekonomik bir kazanç merkezi olmaktan ziyade ortak bilimsel çalışmaları destekleyen ve bölgede yaşayan yerli halkların ve toplulukların sosyoekonomik koşullarını ve insani gelişim düzeylerini artıracak önlemleri önceleyen politikalar geliştirmeleri daha önemlidir. Özellikle Arktik Konsey ve Barents Avro-Arktik Konseyi ${ }^{9}$ bünyesinde oluşturulan çalışma gruplarının faaliyetlerinin gelecekte bölgesel iş birliğinin sürekliliğini sağlamak açısından anahtar rol üstleneceği düşünülmektedir. RF'nin Norveç'le Svalbard bölgesinde ve ABD ile Bering Denizi'nde yaşadığ1 sorunları uluslararası hukuk kurallarına uygun bir biçimde çözme gayreti ve kıta sahanlığını genişletmeye yönelik hak taleplerini yine aynı yolla sürdürme çabası, bu düşünceyi destekler niteliktedir. Nitekim bağlayıcı bir özellik taşımamasına karşın uzman kişilerce oluşturulan çalışma gruplarının hazırlayacakları raporlar bölgesel iş birliğine yön verilmesi ve özellikle çevresel sorunlara yönelik çözümler üretilmesi bağlamında oldukça faydalı bir işleve sahiptir.

\section{KAYNAKÇA}

Alexandrov, O. (2009). "Labyrinths of the Arctic Policy", Russia in Global Affairs 3.

Astrasheuskaya, N; Foy, H. (2019). "Polar Powers: Russia's Bid for Supremacy in the Arctic Ocean", 28 Nisan, https://www.ft.com/content/2fa82760-5c4a-11e9-939a-341f5ada9d40, Erişim Tarihi 20 Temmuz 2020.

Atland, K. (2008). "Mikhail Gorbachev, The Murmansk Initiative, and the Desecuritization of Interstate: Relations in the Arctic", Cooperation and Conflict, Vol. 43, No:3, ss.289-311.

Belov, P. (2012). Resource- Demographic Aspects of Russia's Arctic Geopolitics. In Geopolitics: Theory, History, Practice. Moscow.

Brady, A. M. (2014). “China's Undeclared Arctic Foreign Policy”, Arctic 2014: Who Gets A V oice and Why It Matters: Polar Initiative Policy Brief Series, Wilson Center.

Breum, M. (2019). "Why President Trump's Idea to Buy Greenland is not A Joke in Denmark and Greenland", Arctic Today, 23 Ağustos, s. 2.

Brown, C. (1997). Understanding International Relations, Houndmills, Mcmillan.

Buchanan, E. (2020). “There is No Arctic Axis”, Foreign Policy, 21 Temmuz.

Bull, H. (1966). "The Grotian Conception of International Society" Herbert Butterfield ve Martin Wight (ed.), Diplomatic Investigations, London, Allen and Unwin.

Bull, H. (1977). The Anarchical Society: A Study of Order in World Politics, London, Macmillan.

Bull, H. (1986). Anarchical Society; Martin Wight, Power Politics, Hedley Bull ve Carsten Holbraad (der.), Londra, Penguin, 2. bask1.

Byers, M. (2009). Who Owns the Arctic?: Understanding Sovereignty Disputes in the North, Douglas \& McIntyre, 1st Edition, Canada, 2009.

Chen, G. (2012). "China's Emerging Arctic Strategy”, The Polar Journal, 2, ss. 357-71.

Chorush, A. J. (2020). "Prepared to Go Fully Kinetic": How U.S. Leaders Conceptualize China's Threat to Arctic Security", The Arctic Institute's China Series.

Çin Halk Konseyi [The State Council Information Office of the People's Republic of China] (2018). "China's Arctic Policy", January, http://english.gov.cn/archive/white paper/2018/01/26/content 281476026660336.htm, Erişim Tarihi 24 Haziran 2020.

\footnotetext{
${ }^{9}$ Barents Avrupa-Arktik Konseyi, Barents bölgesiyle ilgili konularda hükümetler arası işbirliği forumudur. Detaylı bilgi için bknz: https://www.barentscooperation.org/en/Barents-Euro-Arctic-Council.
} 
Caymaz, E., \& Büyüksağnak, Y. B. (2021). Rusya Federasyonu ve Amerika Birleșik Devletleri'nin Arktik Bölgesi'ndeki uyuşmazlık konularına yönelik İngiliz Okulu Perspektifi'nden bir analiz. Journal of Human Sciences, 18(1), 76-93. doi:10.14687/jhs.v18i1.6094

Department of Defense (DoD), (2013). "Arctic Strategy", Kasim https://dod.defense.gov/Portals/1/Documents/pubs/2013 Arctic Strategy.pdf, Son Erişim Tarihi 15 Ağustos 2020.

Department of Defense (DOD), (2019). "Annual Report to Congress: Military and Security Developments Involving the People's Republic of China 2019”, https://media.defense.gov/2019/May/02/2002127082/-1/-

1/1/2019 CHINA MILITARY POWER REPORT.pdf. Son Erişim tarihi 24 Haziran 2020 .

Department of the Navy (2015). A Cooperative Strategy for 21st Century Seapower: Forward, Engaged, Ready, s. 6. http://www.navy.mil/local/maritime/150227-CS21RFinal.pdf, Son Erişim Tarihi 13 Temmuz 2020.

Devlen, B.; Özdamar, Ö. (2010). "Uluslararası İlişkilerde İngiliz Okulu Kuramı: Kökenleri, Kavramları ve Tartışmaları", Uluslararası İlișkiler, Cilt 7, Sayı 25 (Bahar), s. 43-68.

Devlen, B.; James, P.; Özdamar, Ö. (2005). "The English School, International Relations and Progress”, International Studies Review, Cilt 7, s.171-197.

Dunne, T. (1998). Inventing International Society: A History of the English School, London, Macmillan, 1998.

Gül, T. (2014). “Arktikte’ki Rusya: Sorun ve Issbirliugi Arasindaki Gel-Git’, Bilgesam Analiz, No.1167.

Heininen, L. (2011). "Arctic Strategies and Policies - Inventory and Comparative Study", The Northern Research Forum \&The University of Lapland. Akureyri, Iceland, August.

Heininen, L.; Sergunin, A.; Yarovoy, G. (2014). Russian Strategies in the Arctic: Avoiding a New Cold War, Valdai Discussion Club Grantees Report, Moscow, September, s. 74.

Hong, N. (2012). 'The Melting Arctic and Its Impact on China's Maritime Transport”, Research in Transportation Economics, Vol. 35, No. 1, ss. 50-57.

Huebert, R. (2019). “A New Cold War in the Arctic?! The Old One Never Ended!", Arctic Yearbook, https://arcticyearbook.com/arctic-yearbook/2019/2019-commentaries/325-a-new-coldwar-in-the-arctic-the-old oneneverended\#: :text $=$ Thus $\% 20$ throughout $\% 20$ the $\% 20$ Cold $\% 20$ War, strategic $\% 20$ impor tance $\% 20$ of $\% 20$ the $\% 20$ Arctic, Erişim Tarihi 1 Temmuz 2020.

Jakobson, L. (2010). "China Prepares for An Ice-Free Arctic”, SIPRI Policy Paper, No. 2.

Jakobsen, L; Peng, J. (2012). "China’s Arctic Aspirations", SIPRI Policy Paper 34, November.

Jacobsen, M.; Herrmann, V. (2017). "Arctic International Relations in a Widened Security Perspective", Politik, 20(3), ss.6-14.

Klimenko, E. (2020). "Russia's New Arctic Policy Document Signals Continuity Rather Than Change", Stockholm International Peace Research Institute, Nisan.

Kopra, S. (2020). "China and its Arctic Trajectories", The Arctic Institute's China Series.

Kraska, J. (2009). "International Security and International Law in the Northwest Passage", V anderbilt Journal of Transnational Law 42, 1109-1132.

Lanteigne, M. (2016). "China and the Northern Sea Route: Placing Their Bets", Arctic Journal, August. Lanteigne, M. (2019). "The Changing Shape of Arctic Security”, NATO Review, June.

Little, R. (1998). "International System, International Society, and World Society: A Re-Evaluation of the English School", B.A Roberson (der.), International Relations Theory. London, Pinter.

Little, R. (1995). "Neorealism and the English School: A Methodological, Ontological, and Theoretical Reassessment", European Journal of International Relations, Cilt 1, Say1 1, s. 934. s. 18.

Medvedev, D. (2008). "Foundations of the State Policy of the Russian Federation in the Arctic up to and Beyond 2020" [Osnovy Gosudarstvennoi Politiki Rossiiskoi Federatsii v Arktike na Period do 2020 Goda I Dal'neishuiu Perspektivu] http://www.rg.ru/2009/03/30/arktikaosnovy-dok.html, (Erişim Tarihi 25 Temmuz 2020).

McDaniel, C. P. (2017).“Russia's Arctic Strategy: An Analysis of the Role of Diplomatic, Cooperative, and Domestic Policies", The Arctic Institute. 
Caymaz, E., \& Büyüksağnak, Y. B. (2021). Rusya Federasyonu ve Amerika Birleșik Devletleri'nin Arktik Bölgesi'ndeki uyuşmazlık konularına yönelik İngiliz Okulu Perspektifi'nden bir analiz. Journal of Human Sciences, 18(1), 76-93. doi:10.14687/jhs.v18i1.6094

Mikhail Gorbachev's Speech in Murmansk at the Ceremonial Meeting On the Occasion of the Presentation of the Order of Lenin and the Gold Star to the City of Murmansk, 1 Ekim 1987, https://www.barentsinfo.fi/docs/Gorbachev speech.pdf, Erişim Tarihi 1 Temmuz 2020.

Moore, J. N. (2004). United States Adherence to the Law of the Sea Convention A Compelling National Interest. http://www.virginia.edu/colp/pdf/house-testimony.pdf, Son erişim Tarihi 13 Haziran 2020.

National Security Decision Memorandum 144, "United States Arctic Policy and Arctic Policy Group" National Security Council, 1971.

National Security Decision Memorandum 202, “Arctic Program Review and Recommendations National Security Council, 1973.

National Security Decision Directive 90, "United States Arctic Policy" National Security Council, 1983.

NSPD 66/HSPD 25 (2009). (National Security Presidential Directive 66/Homeland Security Presidential Directive 25. https:// fas.org/irp/offdocs/nspd/nspd-66.htm, Son Erişim Tarihi 13 Haziran 2020.

Ohnishi, F. (2014). "The Struggle for Arctic Regional Order: Developments and Prospects of Arctic Politics”, Eurosia Border Review, 5(2), ss.81-97.

Oreshenkov, A. (2009). “Arctic Diplomacy,” Russia in Global Affairs, (4) October-December. http:/ / eng.globalaffairs.ru/number/n_14250, Son Erişim Tarihi 13 Haziran 2020.

Østerud, Ø.; Hønneland, G (2014). "Geopolitics and International Governance in the Arctic", Arctic Review on Law and Politics, Volume 5, ss. 156-176.

Özman, A. (1984). Birleşmiş Milletler Deniz Hukuku Sözleşmesi. İstanbul Deniz Ticaret Odas1.

Parnemo, L. K. (2019). "Russia's Naval Development - Grand Ambitions and Tactical Pragmatism”, The Journal of Slavic Military Studies, 32:1, ss. 41-69.

Pompeo, M. R. (2019). "US Warns Beijing's Arctic Activity Risks Creating 'New South China Sea”, The Guardian: https://www.theguardian.com/world/2019/may/06/pompeo-arcticactivity-new-south-china-sea. Son Erişim Tarihi 13 Ağustos 2020.

Pompeo, M. R. (2019). "Looking North: Sharpening America's Arctic Focus, 2019, https://www.state.gov/looking-north-sharpening-americas-arctic-focus/, Erişim Tarihi 17 Haziran 2020.

Putin, V. (2013). Strategiya Razvitiya Arkticheskoi Zony Rossiyskoi Federatsiii Obespecheniya Natsional'noi Bezopasnosti na Period do 2020 Goda [The Strategy for the Development of the Arctic Zone of the Russian Federation and Ensuring National Security for the Period up to 2020]. Approved by President Vladimir Putin on February 20, 2013 http://правительство.pф/docs/22846/, Erişim Tarihi 25 Temmuz 2020.

Rosneft, (2013). 'Rosneft And Sinopec Agree Memorandum on Prepaid Export Contract', Press Release, 22 Ekim, https://www.rosneft.com/press/releases/item/24362/ Erişim tarihi 17 Haziran 2020.

Schepp, M.; Traufetter, G. (2009). "Riches at the North Pole: Russia Unveils Aggressive Arctic Plans," Spiegel Online International, 29 January. Available at: http://www.spiegel.de/international/world/riches-at-the-north-pole-russia-unveilsaggressive-arctic-plans-a-604338.html, Erişim Tarihi 3 Ağustos 2020.

Sun, Y. (2020). "Defining Chinese Threat in the Arctic", The Arctic Institute's China Series.

The Maritime Executive (2 Mart 2018), "China Surpasses U.S. as Largest Crude Oil Importer", s.1.

The Stimson Center, (2013). "Evolution of Arctic Territorial Claims and Agreements: A Timeline (1903-Present), 15 Eylül, https://www.stimson.org/2013/evolution-arctic-territorial-claimsand-agreements-timeline-1903-present/, Erişim Tarihi 3 Ağustos 2020.

White House, (1994). "United States Policy on the Arctic and Antarctic Regions", Presidential Decision Directive / NSC-26. 
Caymaz, E., \& Büyüksağnak, Y. B. (2021). Rusya Federasyonu ve Amerika Birleșik Devletleri'nin Arktik Bölgesi'ndeki uyuşmazlık konularına yönelik İngiliz Okulu Perspektifi'nden bir analiz. Journal of Human Sciences, 18(1), 76-93. doi:10.14687/jhs.v18i1.6094

White House, (2009). “Arctic Region Policy", National Security Presidential Directive-66 / Homeland Security Presidential Directive-25.

White House, (2013). "National Strategy For The Arctic Region": https://polarconnection.org/usnational-strategy-arctic-region-may-

2013/\#: : text $=$ The $\% 20$ Strategy $\% 20$ identifies $\% 20$ three $\% 20 \mathrm{key}$,Strengthen $\% 20$ Internation al\%20Cooperation, Erişim Tarihi 3 Ağustos 2020.

Wight, M. (1991). International Theory: The Three Traditions, Brian Porter ve Gabriele Wight (der.), Leicester, UK: Leicester University Press/Royal Institute of International Affairs.

Watson, A. (1987). "Hedley Bull, State Systems, and International Studies", Review of International Studies, Cilt 13, Say1 2.

Wight, M. (1977). "Systems of States", Hedley Bull (der.), Christianity, Diplomacy, and War, Leicester, UK: Leicester University Press.

Wight, M. (1966). Why Is There No International Theory?, Herbert Butterfield ve Martin Wight(der.), Diplomatic Investigations, London, Allen and Unwin.

Wight, M. (1953). Systems of States; Herbert Butterfield, Christianity, Diplomacy, and War, Londra, Epworth.

Willett, L. (2009). The Navy in Russia’s “Resurgence”, RUSI Journal, 154: 1, pp. 50-55.

\section{Extended English Summary}

There are different views on the Arctic policies of the Russian Federation (RF) in the literature. The RF's decision to continue its strategic bomber patrols in the Arctic Region, its placement of the Russian flag made of titanium on the ocean floor at the North Pole in August 2007, and the scope of the Arctic Strategy published in 2008 based on the aggressive, expansionist and 'power diplomacy' of Arctic politics haveled to serious criticism.

On the other hand, there are also views that explain the current Arctic doctrine of the RF with its pragmatic interests such as competition for natural resources and / or control of the Northern Sea Route, unlike the Cold War period, which was driven by ideological or geopolitical factors. For this reason, there are studies that consider the intentions of the RF towards the Arctic Region as defensive to protect its legitimate interests, or at least as acceptable as the demands of other Arctic states in the context of international Arctic cooperation. In these studies, it is emphasized that Moscow's primary interest is the development of the RF Arctic Region, which is rich in natural resources and is less developed in terms of local economy, infrastructure, communication systems, social institutions and culture. According to this view, Moscow does not follow a revisionist Arctic policy, on the contrary, it tries to resolve all the disputed issues it encounters in the region through peaceful means offered by international law, by bringing them to international organizations.

The current Arctic doctrine of the United States of America (USA) contains many subheadings. United States, has military and strategic interests in the Arctic Region, including missile defense and early warning systems where naval and air systems that provide replenishment capability at strategic points are deployed, demonstrating its presence in the Arctic Ocean and maintaining maritime security operations, navigation, over-flight freedom and strategic deterrence. In addition, the United States has a national interest in preventing any terrorist or other criminal acts that could expose the Arctic Region. Finally, due to the economic and political interests of the USA in the region, it is of great importance in terms of expanding its presence and activities in the region and increasing its naval power.

Based on the information given above, the disputes regarding the continental shelf, which have come to the fore in the Arctic Region, where powerful states located, are understandable. Although there are many studies in the Turkish literature that examine the conflicts in the Arctic 
Caymaz, E., \& Büyüksağnak, Y. B. (2021). Rusya Federasyonu ve Amerika Birleșik Devletleri'nin Arktik Bölgesi'ndeki uyuşmazlık konularına yönelik İngiliz Okulu Perspektifi'nden bir analiz. Journal of Human Sciences, 18(1), 76-93. doi:10.14687/jhs.v18i1.6094

Region of the RF and the USA, existing studies generally present analyzes within the framework of realist theory. In today's world where the actors are diversified with globalization, in a multinational region such as the Arctic Region, which has great potential in terms of both natural resources and maritime trade routes and has been subject to many conflicts in the past, the issues of conflict between powerful actors such as the USA and RF and including many different variables are analysis in context has limited the scope of the available analysis. In this study, the aforementionedissues are examined from the perspective of the English School, which can synthesize the traditions of realism, rationalism and revolutionism and present a unique framework, and possibleproposals in accordance with international law, the role and function of the People's Republic of China (PRC), which has led to various discussions with its investments and cooperation agreements in the region, in the struggle for domination in the region has also been included in the analysis.

Although the contradictory articles of UNCLOS, which guides the legal regulations for the region, cause conflicts between states, the importance of international organizations operating in the region in establishing dialogue and resolving disputes is revealed. In order to develop the cooperation potential in the Arctic Region and turn it into a peace area in the process, the international community, especially littoral states are supposed to develop policies that support joint scientific studies and prioritize measures to increase the socio-economic conditions and human development levels of indigenous peoples and communities living in the region, rather than being a commercial and economic gain center provided by the rich energy resources and new maritime transportation / trade routes that emerge due to global warming. It is believed that the activities of the Arctic Council and the working groups for the realization of the Barents EuroArctic Council will play a key role in ensuring the continuity of cooperation in the future. 